УДК 342. 951:347.77

DOI https://doi.org/10.32837/pyuv.v0i2(27).197

\author{
O. М. Коротун \\ кандидат юридичних наук, докторант \\ Науково-дослідного інституту публічного права
}

\title{
МЕТОДИ УПРАВЛІНСЬКОЇ ДІЯЛЬНОСТІ У СФЕРІ ЗАБЕЗПЕЧЕННЯ ОХОРОНИ ПРАВ СУБ'ЄКТІВ ІНТЕЛЕКТУАЛЬНОЇ ВЛАСНОСТІ
}

Нагальною науковою і практичною проблемою є розкриття особливостей адміністративно-правового забезпечення охорони прав суб'єктів інтелектуальної власності, яке під впливом правотворчих дій з прикладних аспектів характеризуються низкою проблем у правозастосуванні, не останнє місце серед яких займає питання впливу норм адміністративного права на регулювання суспільних відносин у сфері охорони та захисту правовласників об’єктів права інтелектуальної власності.

Серед забезпечувального блоку реалізації адміністративно-правових та організаційних методів у сфері забезпечення охорони прав суб'єктів інтелектуальної власності важливе значення мають характерні особливості специфічної діяльності публічної адміністрації, яка через реалізацію функційних повноважень здійснює за допомогою визначених нормативно-правових актів управлінську діяльність. Забезпечення досягнення бажаного - охорони прав суб'єктів інтелектуальної власності, інших учасників правовідносин у цій сфері (громадян, юридичних осіб, держави) здійснюється винятково в рамках закону і передбачає вжиття юридичних заходів впливу (в тому числі й примусових).

Дослідженням методів державного управління займалися такі вчені-адміністративісти, як Ю.П. Битяк, В.В. Галунько, Т.О. Коломоєць, Ю.І. Крегул, О.П. Світличний, С.Г. Стеценко. Однак питання методів управлінської діяльності у сфері інтелектуальної власності є малодослідженими в юридичній науці, що й зумовлює актуальність цієї статті.

Мета статті полягає у дослідженні методів управлінської діяльності та розкритті шляхів здійснення цілеспрямованого впливу такої діяльності на сферу забезпечення охорони прав суб’єктів інтелектуальної власності.

Державний вплив щодо впорядкування суспільних відносин у досліджуваній сфері здійснюється відповідно до встановлених нормами адміністративного права прав і обов'язків, проте сучасні тенденції правового регулювання не завжди враховують об'єктивну закономірність щодо забезпечення належної охорони прав суб'єктів інтелектуальної власності, права яких мають відношення до окремих правових режимів об'єктів інтелектуальної власності. Законодавець, який виступає гарантом забезпечення охорони прав інтелектуальної власності, не завжди враховує практичний складник цієї проблеми.

Отже, діяльність публічної адміністрації у сфері забезпечення охорони прав суб'єктів інтелектуальної власності виявляється у конкретних взаємозв' язках, завдяки яким управлінська діяльність набуває певних форм і методів. Для розкриття специфіки діяльності публічної адміністрації необхідно проаналізувати обов'язковий атрибут їх діяльності - методи управління. Загалом же варто наголосити на тому, що специфіка діяльності публічної адміністрації щодо забезпечення охорони прав суб'єктів інтелектуальної власності зумовлюється як кількістю правовласників об'єктів інтелектуальної власності, так і значною кількістю цих об'єктів. Це зумовлює специфічні адміністративно-правові методи діяльності.

Крім форм управлінської діяльності, нормативно-правовий блок передбачає реалізацію адміністративно-правових та організаційних методів забезпечення охорони прав суб'єктів інтелектуальної власності. За допомогою норм адміністративного права закріплюються повноваження публічної адміністрації, права і обов'язки учасників правовідносин у сфері інтелектуальної власності. У межах визначеної компетенції публічна адміністрація для виконання поставлених завдань використовує адміністративно-правові методи. Внаслідок значної кількості суб'єктів публічної адміністрації у сфері інтелектуальної власності та об'єктів адміністративно-правової охорони методи управління теж є різноманітними, що не виключає наявності у них загальних рис.

Найбільш характерними рисами для методів управління є такі: 1) способи впливу виконавчого органу (посадової особи) на підпорядкований йому орган та громадян; 2) вираження державного публічного інтересу, керівної ролі держави; 3) способи досягнення мети; 4) способи організації, прийоми здійснення функцій, що виникають в процесі здійснення спільної діяльності; 5) способи реалізації компетенції [1, с. 146-147].

У юридичній літературі під методами адміністративного права розуміють способи та прийоми цілеспрямованого впливу норм адміністративного права на поведінку учасників адміністративно-правових відносин [2, с. 156]. На думку 
О.П. Світличного, методи публічного управління інтелектуальною власністю є способами практичного здійснення органами виконавчої влади та ïx посадовими особами владно-організаційного впливу на керовані об'єкти відповідно до наданих їм повноважень [3, с. 38].

Наявність схожих ознак дає підстави говорити, однак, про різні концептуальні підходи науковців до розкриття адміністративно-правових методів, які відображають взаємозв'язок керуючих і керованих підсистем через загальну категорію «методи адміністративного права», методи управління, державного управління, методи впливу суб'єктів публічної адміністрації, методи публічного управління. Вказані правові методи адміністративного інструментарію $є$ актуальними в теорії адміністративного права, однак вони також найбільш влучно характеризують юридичну природу сучасного адміністративного права (методи управління публічної адміністрації).

У такому розумінні реалізація адміністративно-правових та організаційних методів у досліджуваній сфері здійснюється публічною адміністрацією в концентрованій формі. Методи управління публічної адміністрації характеризуються такими рисами: вони пов'язані з цільовим призначенням управлінської діяльності спеціально уповноважених державних органів, інших суб'єктів публічної адміністрації з метою практичної реалізації завдань і функцій держави у сфеpi охорони інтелектуальної власності, виражають владно-організаційний вплив на керований об'єкт шляхом використання адміністративно-правових форм і методів управління; як правильно поєднані методи управління публічної адміністрації вони створюють єдину взаємопов'язану систему способів впливу на керовані об'єкти; суб'єкти публічної адміністрації використовують адміністративний інструментарій (способи реалізації управлінської діяльності), виражають державно-владний характер, завжди маючи відповідні керовані об'єкти; реалізація адміністративно-правових форм управління залежать від правового статусу суб'єкта публічної адміністрації та особливостей керованого об'єкта (індивідуального або колективного, форм власності) через застосування різноманітних заходів впливу, в тому числі й адміністративного примусу.

Взявши за основу вищевикладені методи державного управління, здійснимо їх дослідження на прикладі діяльності окремих органів публічної адміністрації у сфері охорони інтелектуальної власності. У межах визначених нормативно-правовими актами повноважень публічна адміністрація використовує адміністративний інструментарій (способи реалізації управлінської діяльності), завжди маючи відповідні керовані об'єкти, які виражають державно-владний характер. Кожен із органів публічної адміністрації в межах своєї компетенції приймає управлінське рішення, яке є обов'язковим для підпорядкованого органу управління. Водночас сфера державного управління інтелектуальною власністю охоплює широке коло різних об'єктів права інтелектуальної власності, що передбачає розмежування способів здійснення владно-організаційного впливу керуючих суб'єктів на підпорядковані їм суб'єкти публічної адміністрації та керовані об'єкти. Наприклад, якщо це стосується охорони права інтелектуальної власності на торговельну марку, інших об'єктів промислової власності, безпосередніми суб'єктами державного управління є Міністерство економічного розвитку і торгівлі України (Мінекономрозвитку), Департамент інтелектуальної власності, Український інститут промислової власності, а якщо це стосується охорони авторського права або охорони суміжних прав, то такими суб'єктами є Мінекономрозвитку, Департамент інтелектуальної власності, державні інспектори з питань інтелектуальної власності. Кожен із вказаних суб'єктів публічної адміністрації займає своє місце в організаційній структурі забезпечення охорони прав суб'єктів інтелектуальної власності відповідно до компетенції, визначеної нормативно-правовими актами.

Вказана сукупність суб'єктів публічної адміністрації являє собою розгалужену керівну систему суб'єктів публічної адміністрації у сфері охорони інтелектуальної власності. Наприклад, затвердивши уніфіковану форму акта, складеного за результатами проведення планового (позапланового) заходу державного нагляду (контролю) щодо дотримання суб'єктом господарювання вимог законодавства у сфері інтелектуальної власності, та форму припису щодо усунення порушень, виявлених під час проведення планового (позапланового) заходу державного нагляду (контролю) щодо дотримання суб'єктом господарювання вимог законодавства у сфері інтелектуальної власності, Мінекономрозвитку - суб’єкт управління, керуючись нормами спеціального законодавства у сфеpi охорони інтелектуальної власності, зобов'язує Департамент інтелектуальної власності забезпечити подання цього наказу в установленому законодавством порядку на державну реєстрацію [4]. У такому разі адресатами є підпорядковані Мінекономрозвитку державні інспектори $з$ питань інтелектуальної власності. Це свідчить про те, що методи управління проявляються шляхом взаємодії суб'єктів управління.

Методи контролю і нагляду належать до загальних методів діяльності публічної адміністрації. Правильно поєднані методи управління публічної адміністрації створюють єдину взаємопов'язану систему способів впливу на керовані об'єкти. 3 використанням адміністративного ін- 
струментарію (способів реалізації управлінської діяльності) та 3 наявності відповідних керованих об’єктів реалізація адміністративно-правових методів публічною адміністрацією залежать від правового статусу суб'єкта та особливостей керованого об'єкта (індивідуального або колективного). Від цього залежать особливості реалізації адміністративно-правових та організаційних методів у сфері забезпечення охорони прав суб'єктів інтелектуальної власності, в тому числі й у сфері застосування адміністративного примусу.

У практичній діяльності публічної адміністрації, тобто у контексті відносин із учасниками правовідносин у сфері інтелектуальної власності, важливе місце посідають методи переконання i примусу, які, на думку А.Т. Комзюка, є найвагомішими методами адміністративного права [5, с. 19].

3 метою забезпечення охорони прав суб'єктів інтелектуальної власності суб'єкти публічної адміністрації проводять різноманітні адміністративно-попереджувальні заходи, здійснюючи які, вони зобов'язані враховувати охоронну специфіку об'єктів інтелектуальної власності. Зокрема, таким заходом є реєстрація об'єктів права інтелектуальної власності на митниці, після чого митні органи на підставі даних реєстру вживають заходів щодо запобігання переміщенню через митний кордон України контрафактних товарів.

Наведене є свідченням того, що переважно адміністративно-попереджувальні заходи виражаються у вигляді певних обмежень і заборон. У разі необхідності суб'єкти публічної адміністрації застосовують адміністративний (державний) примус. Водночас ми вважаємо, що поєднання адміністративних методів як способів або засобів впливу на діяльність суб'єктів господарювання (особливо шляхом застосування методів нагляду (контролю) та економічних методів) дозволяє досягти більш дієвого ефекту на суб'єктів господарювання, діяльність яких пов'язана із об'єктами права інтелектуальної власності.

Проведене дослідження особливостей реалізації адміністративно-правових та організаційних методів у сфері забезпечення охорони прав суб'єктів інтелектуальної власності свідчить про різноманіття методів адміністративно-правового регулювання правовідносин у сфері охорони інтелектуальної власності. Специфіка адміністративно-правових методів, що використовуються публічною адміністрацією, залежить від правового статусу суб'єкта публічної адміністрації, особливостей керованого об'єкта та специфіки охорони об'єктів права інтелектуальної власності.

Забезпечення охорони прав суб'єктів інтелектуальної власності має в цьому аспекті свою специфіку, яка полягає в особливому об'єкті - об'єк- ті права інтелектуальної власності. А це означає, що з огляду на специфіку охорони об'єктів права інтелектуальної власності об'єкт управління в одному випадку спроможний використовувати весь арсенал різноманітних адміністративно-правових методів, а в іншому випадку він обмежений у їх використанні.

Внаслідок значного різноманіття об'єктів права інтелектуальної власності, а також кількості суб'єктів права інтелектуальної власності - керованих об'єктів, що перебувають під впливом керуючих суб'єктів, методи управління теж є різноманітними. Ці методи залежать від цілей і завдань, які стоять перед суб'єктом публічної адміністрації. Методи управління, що виражають різні аспекти практичної діяльності різних суб'єктів публічної адміністрації, певною мірою залежать і від стану законодавчого регулювання охорони прав того чи іншого об'єкта права інтелектуальної власності, особливостей керованого об'єкта. Це надає широкий вибір різних адміністративно-правових методів.

Під адміністративно-правовими методами забезпечення охорони прав суб'єктів інтелектуальної власності слід розуміти способи та прийоми безпосереднього і цілеспрямованого впливу суб'єктів публічної адміністрації (посадових осіб) на підставах закріпленої за ними компетенції та у встановлених межах і відповідній формі на підпорядковані їм органи та керовані об’єкти.

\section{Jimepamypa}

1. Адміністративне право України : підручник / Ю.П. Битяк, В.В. Багуцький, В. М. Гаращук та ін. ; за ред. Ю.П. Битяка. Харків : Право, 2001. 528 с.

2. Галунько В.В. Адміністративне право України : підручник : у 2-х т. Загальне адміністративне право. Академічний курс. Херсон : ХМД, 2013. Т. 1. 396 с.

3 . Світличний О.П. Метод як один із елементів змісту управлінської діяльності у сфері інтелектуальної власності. Науковий вісник Національного університету біоресурсів і природокористування України. Серія «Право». 2017. № 264. С. 33-38.

4. Про затвердження уніфікованої форми акта, складеного за результатами проведення планового (позапланового) заходу державного нагляду (контролю) щодо дотримання суб'єктом господарювання вимог законодавства у сфері інтелектуальної власності, та форми припису щодо усунення порушень, виявлених під час проведення планового (позапланового) заходу державного нагляду (контролю) щодо дотримання суб'єктом господарювання вимог законодавства у сфері інтелектуальної власності : наказ Мiністерства економічного розвитку і торгівлі України № 96 від 29.01.2019 р. URL: https://ips.ligazakon.net/ document/view/RE33123?an=481.

5. Комзюк А.Т. Заходи адміністративного примусу в правоохоронній діяльності міліції: поняття, види та організаційно-правові питання реалізації. Харків : Вид-во Нац. ун-ту. внут. справ. 2002. 336 с. 


\section{Анотація}

Коротун О. М. Методи управлінської діяльності у сфері захисту прав інтелектуальної власності. Стаття.

Широкий аспект питань, пов'язаних з правовим захистом інтелектуальної власності, спонукає автора звернутися до різних теоретичних джерел. В основі правового спрямування цієї статті лежать концепції та доктринальні підходи представників адміністративного права до вирішення проблеми. 3 метою розкриття специфіки діяльності державного управління було проаналізовано обов'язковий їх атрибут - методи управління. Цікавим $є$ те, що специфіка форм діяльності публічної адміністрації щодо забезпечення захисту прав інтелектуальної власності пов'язана 3 кількістю власників прав інтелектуальної власності та великою кількістю їх об'єктів. Це визначає конкретні адміністративно-правові методи діяльності.

Автор звертає увагу, що процес реалізації функцій державного управління передбачає впровадження адміністративно-правових та організаційних методів. 3 цією метою аналізуються такі аспекти діяльності: концептуальні підходи вчених до запровадження адміністративно-правових методів, що відображають взаємозв'язок керівної системи та керованої підсистеми; виконавча та адміністративна діяльність суб'єктів державного управління; нормативно-правові акти, що стосуються конкретної діяльності державного управління у сфері захисту інтелектуальної власності. На основі аналізу методів управлінської діяльності доведено, що за допомогою використання адміністративних інструментів (методів здійснення управлінської діяльності) та за наявності відповідних керованих об'єктів реалізація адміністративно-правових форм суб'єктом державного управління залежить від правового статусу суб'єкта та характеристики керованого об'єкта. Від цього залежать особливості реалізаціі адміністративно-правових та організаційних методів у галузі захисту прав інтелектуальної власності, у тому числі й із застосуванням адміністративного примусу. Методи управління, що виражають різні аспекти практичної діяльності різних суб'єктів державного управління, певною мірою залежать від стану законодавчого регулювання захисту прав інтелектуальної власності, особливостей керованого об'єкта, що дає широкий вибір використання різних видів адміністративно-правових методів.

Автор визначає поняття «адміністративно-правові методи забезпечення захисту прав інтелектуальної власності» як методи та прийоми прямого та свідомого впливу органів (службових осіб) державного управління на підставі визначеної компетенції.

Ключові слова: методи, управління, безпека, сутність, об’єкти, інтелектуальна власність.

\section{Summary}

Korotun O.M. Methods of management activity in the field of protection of intellectual property rights. - Article.

The broad aspect of issues related to the legal protection of intellectual property prompts the author to turn to various theoretical sources, with the basis of the legal direction of this article are the concepts, concepts and doctrinal approaches of representatives of administrative law to solve the problem. In order to disclose the specifics of the activities of public administration, a mandatory attribute of their activity, management methods, has been analyzed. Attention is drawn to the fact that the specificity of the forms of public administration's activity in securing the protection of intellectual property rights is primarily due to the number of intellectual property right holders and the large number of their objects, which determines the specific administrative and legal methods of activity.

Attention is drawn to the fact that the process of implementation of public administration functions involves the implementation of administrative and legal and organizational methods. To this end, the following are analyzed: conceptual approaches of scientists to the discovery of administrative and legal methods, which reflect the relationship of the managed and managed subsystems; executive and administrative activities of public administration entities; normative-legal acts concerning the specific activity of public administration in the field of intellectual property protection. Based on the analysis of methods of management activity, it is proved that using administrative tools (methods of implementation of management activities) and always having the appropriate managed objects, the implementation of administrative and legal forms by the subject of public administration depend on the legal status of the subject and the characteristics of the managed object (individual or collective, ownership). The peculiarities of the implementation of administrative-legal and organizational methods in the field of protection of intellectual property rights, including the use of administrative coercion, depend on this. Management methods expressing different aspects of the practical activity of different entities of public administration depend to a certain extent on the state of legislative regulation of protection of the rights of an intellectual property right, the features of the managed object, which gives a wide choice of use of different types of administrative - legal methods.

The author defines the concept of "administrative and legal methods of ensuring the protection of intellectual property rights", which means the methods and techniques of direct and deliberate influence of public administration entities (officials) on the grounds of their assigned competence, within the established limits and appropriate forms to their organs and managed objects.

Key words: methods, management, security, entities, objects, intellectual property. 